\title{
Plasma exchange in critically ill COVID-19 patients improved inflammation, microcirculatory clot formation, and hypotension, thereby improving clinical outcomes: fact or fiction?
}

\author{
Patrick M. Honore*, Leonel Barreto Gutierrez, Luc Kugener, Sebastien Redant, Rachid Attou, Andrea Gallerani and \\ David De Bels
}

We read with great interest the recent article by Morath et al. who conclude that plasma exchange (PE) improved inflammation, microcirculatory clot formation, and hypotension, thereby improving clinical outcomes [1]. We would like to make some comments. This is a good example of when misinterpretation of the results can lead to the wrong conclusions. PE has a cutoff of 1,000 , 000 daltons (Da) and can therefore remove many substances. Let us just take the example of the inflammatory mediators C-reactive protein (CRP) and interleukin-6 (IL-6). CRP, in its pentameric form, has a molecular weight of $120,000 \mathrm{Da}$ and in its monomeric form 22,000 Da [2]. IL-6 has a molecular weight of $21,000 \mathrm{Da}$ [3]. It stands to reason that these two inflammatory molecules will be easily removed by PE. Reduction of the plasma level of inflammatory mediators via the use of PE does not necessarily equate to an improvement in the septic status of the patient. It is simply an artificial reduction, "treating the numbers" so to speak. The same is true for ferritin $(474,000 \mathrm{Da}), \mathrm{LDH}(144,000 \mathrm{Da})$, and D-dimers $(180,000 \mathrm{Da})$, where the observed reduction is simply a consequence of removal and not an improvement of the patient's condition. It is also important to note that PE has the potential to cause harm by diluting or attenuating the patient's adaptive response to infection via depletion of immunoglobulins and complement components

\footnotetext{
* Correspondence: Patrick.Honore@CHU-Brugmann.be

ICU Department, Centre Hospitalier Universitaire Brugmann-Brugmann

University Hospital, Place Van Gehuchtenplein, 4, 1020 Brussels, Belgium
}

3 and 4 in individuals treated with plasmapheresis [4]. Importantly, in the case of patients with COVID-19, PE will remove the protective antibodies formed by the patient, which is not desirable. Indeed, PE may not restore immune homeostasis but may rather aggravate immunoparalysis [5]. Look also at the various additional treatments received by the patients: tocilizumab, interferon, prednisolone, immunoglobulins, and convalescent serum [1]. Most of these additional treatments will be easily removed by PE. The authors stated that clinical improvements were achieved with only 1 to $2 \mathrm{PE}$, possibly indicating a direct pathophysiological influence of $\mathrm{PE}$ on the COVID-19-associated cytokine storm-like clinical syndrome [1]. We doubt that this is the case. The only positive effect that we can see is in the control of temperature; perhaps by inducing relative hypothermia, $\mathrm{PE}$ resulted in peripheral vasoconstriction responsible for the weaning of vasopressors.

\section{Abbreviations \\ PE: Plasma exchange; Da: Daltons; CRP: C-reactive protein; IL-6: Interleukin-6; LDH: Lactate dehydrogenase}

\section{Acknowledgements}

None.

Authors' contributions

$\mathrm{PMH}, \mathrm{SR}$, and DDB designed the paper. All authors participated in drafting and reviewing. All authors read and approved the final version of the manuscript.

\section{Funding \\ None.}

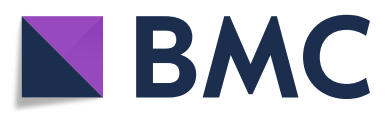

(c) The Author(s). 2020 Open Access This article is licensed under a Creative Commons Attribution 4.0 International License, which permits use, sharing, adaptation, distribution and reproduction in any medium or format, as long as you give appropriate credit to the original author(s) and the source, provide a link to the Creative Commons licence, and indicate if changes were made. The images or other third party material in this article are included in the article's Creative Commons licence, unless indicated otherwise in a credit line to the material. If material is not included in the article's Creative Commons licence and your intended use is not permitted by statutory regulation or exceeds the permitted use, you will need to obtain permission directly from the copyright holder. To view a copy of this licence, visit http://creativecommons.org/licenses/by/4.0/ The Creative Commons Public Domain Dedication waiver (http://creativecommons.org/publicdomain/zero/1.0/) applies to the data made available in this article, unless otherwise stated in a credit line to the data. 
Availability of data and materials

Not applicable.

Ethics approval and consent to participate

Not applicable.

\section{Consent for publication}

Not applicable.

\section{Competing interests}

The authors declare to have no competing interests.

Received: 17 August 2020 Accepted: 24 August 2020

Published online: 07 September 2020

\section{References}

1. Morath C, Weigand MA, Zeier M, Speer C, Tiwari-Heckler S, Merle U. Plasma exchange in critically ill COVID-19 patients. Crit Care. 2020;24:481. https:// doi.org/10.1186/s13054-020-03171-3.

2. Honore PM, Jacobs R, Hendrickx I, De Waele E, Van Gorp V, Spapen HD. 'Biomarking' infection during continuous renal replacement therapy: still relevant? Crit Care. 2015;19(1):232. https://doi.org/10.1186/s13054-015-0948z.

3. Tosato G, Tanner J, Jones KD, Revel M, Pike SE. Identification of interleukin-6 as an autocrine growth factor for Epstein-Barr virus-immortalized B cells. J Virol. 1990;64(6):3033-41. https://doi.org/10.1128/JVI.64.6.3033-3041.1990.

4. Rimmer E, Houston BL, Kumar A, Abou-Setta AM, Friesen C, Marshall JC, et al. The efficacy and safety of plasma exchange in patients with sepsis and septic shock: a systematic review and meta-analysis. Crit Care. 2014 Dec 20;18(6):699. https://doi.org/10.1186/s13054-014-0699-2.

5. Szczeklik W, Wawrzycka K, Włudarczyk A, Sega A, Nowak I, Seczyńska B, et al. Complications in patients treated with plasmapheresis in the intensive care unit. Anaesthesiol Intensive Ther. 2013 Jan-Mar;45(1):7-13. https://doi.org/10. 5603/AIT.2013.0002.

\section{Publisher's Note}

Springer Nature remains neutral with regard to jurisdictional claims in published maps and institutional affiliations. 